\title{
Arsenic, Copper, Molybdenum, and Selenium Exposure through Drinking Water in Rural Eastern Croatia
}

\author{
Mario Ćurković1*, Laszlo Sipos², Dinko Puntarić ${ }^{3}$, Katarina Dodig-Ćurkovićc \\ Nela Pivac ${ }^{5}$, Kristina Kralik ${ }^{6}$ \\ ${ }^{1}$ Department of Family Medicine, Josip Juraj Strossmayer University of Osijek, Medical School Osijek, Croatia \\ ${ }^{2}$ University of Zagreb, Faculty of Chemical Engineering and Technology, Zagreb, Croatia \\ ${ }^{3}$ Department of Public Health, Josip Juraj Strossmayer University of Osijek, Medical School Osijek, Croatia \\ ${ }^{4}$ Department of Psychiatry, Josip Juraj Strossmayer University of Osijek, Medical School Osijek, Croatia \\ ${ }^{5}$ Division of Molecular Medicine, Rudjer Boskovic Institute, Zagreb, Croatia \\ ${ }^{6}$ Department of Biophysics, Medical Statistics and Medical Informatics, \\ Josip Juraj Strossmayer University of Osijek, Medical School Osijek, Croatia
}

Received: 14 July 2014

Accepted: 11 February 2016

\begin{abstract}
The objectives of this study were to determine the concentrations of arsenic, copper, molybdenum, and selenium in drinking water and biological tissues (serum, urine, hair) in the populations of three rural communities in eastern Croatia, and to determine whether the concentrations of these elements in drinking water can be related to their concentrations in biological tissues. Arsenic, copper, molybdenum, and selenium concentrations were determined using inductively coupled plasma mass spectrometry in the samples of water, urine, and serum of the subjects from all three communities, while hair samples were taken from the subjects from Ćelije and Draž. The highest arsenic concentrations in drinking water and biological tissues were found in the participants from Ćelije. In all three communities, concentrations of copper, molybdenum, and selenium did not exceed maximum permissible concentrations in drinking water or in biological tissues.
\end{abstract}

Keywords: arsenic, copper, molybdenum, selenium, spectrometry

\section{Introduction}

Arsenic is an element that is widely distributed throughout the world. People can be exposed to arsenic from a variety of sources, which may be natural or a consequence of human activities [1]. Arsenic exposure of humans mainly occurs from the ingestion of water and

*e-mail: mcurkov@yahoo.com food contaminated with arsenic [2]. The occurrence of arsenic in drinking water can be a result of its geological presence in local bedrock [1,3]. Throughout the world groundwater is an important source of drinking water, but it is also a well-known source of arsenic exposure in humans. Exposure to drinking water contaminated with arsenic is a global environmental problem that affects millions of people in different parts of the world [4-9]. Chronic ingestion of drinking water contaminated with arsenic can lead to serious health problems in humans [5, 
10]. The International Agency for Research on Cancer considers arsenic to be a Class I human carcinogen because of its increased risk for skin, lung, and bladder cancer [11]. Arsenic-contaminated water even at a high concentration is translucent, tasteless and odorless which makes it more dangerous for human populations [12].

In contrast to arsenic, which is a well-known toxic agent, copper, molybdenum, and selenium are trace elements that are essential for life $[13,14]$, but they may be toxic when present in excess - especially copper and selenium [14-19]. Ingestion of food and water are the main sources of exposure to copper. Potable drinking water contains low levels of copper, but in private wells high concentrations of copper have been found, or when water or beverages with low $\mathrm{pH}$ have been conducted through the copper piping [20]. The estimate is that the daily intake of copper for the EU population ranges from 0.8 to 1.8 $\mathrm{mg}$ per day. Drinking water contributes marginally to the total copper intake, except in the areas of poor water quality and/or corroded distribution systems [21]. The copper content of foods and drinking water could be quite variable [22]. Food is the main source of selenium in the general population $[23,24]$. Moreover, selenium intake can be increased by the consumption of drinking water containing high concentrations of selenium [25]. Surface and groundwaters contain very variable concentrations of selenium. In some areas, the concentration of selenium in groundwater can reach very high levels (up to $6,000 \mu \mathrm{g} / \mathrm{L}$ ), while the public water systems in developed countries are generally within the reference value of $10 \mu \mathrm{g} / \mathrm{L}$ [23].

For the human population, food is a major source of molybdenum while the concentrations in the water are negligible. Molybdenum is an element that has a relatively low toxicity [18]. In animals, especially ruminants and in humans molybdenum toxicity is more pronounced than its deficit [19]. One case describes an acute poisoning with molybdenum from a dietary molybdenum supplement in a male patient [26]. Concentrations of molybdenum are different depending on the type of water and they range from $0.01 \mathrm{mg} / \mathrm{L}$ in the ocean up to $30 \mathrm{mg} / \mathrm{L}$ in some American rivers. Molybdenum concentrations in drinking water are generally low (up to $6 \mu \mathrm{g} / \mathrm{L}$ ). In the vicinity of the areas where molybdenum ore is mined, contamination of drinking water may occur, leading to daily intakes of more than $1,000 \mu \mathrm{g}$ [23]. The objectives of this study were to determine concentrations of arsenic, copper, molybdenum, and selenium in drinking water and biological tissues (serum, urine, hair) in the population of three rural communities in eastern Croatia, and to determine whether the concentrations of these elements in drinking water can be related to their concentrations in biological tissues.

\section{Materials and Methods}

\section{Participants}

The subjects of the study were 30 people 35 to 75 years old, male and female, living in three communities of eastern Slavonia and Baranja in eastern Croatia: Ćelije, Draž, and Potnjani. We chose those three communities because they are situated in the Pannonian Basin, where groundwater resources are loaded with arsenic, and it is an area where agriculture is the main part of economic activity. In these three communities, people use drinking water from wells (tube well and dug well). The study was performed in accordance with Croatian regulations for the safety of drinking water. The research was conducted as a cross-section of the current state of the population in these communities. The study was approved by the Ethics Committee of the School of Medicine, Josip Juraj Strossmayer University of Osijek, Croatia. The purpose of the study was explained to each participant, after which they voluntarily provided written informed consent. The map of Croatia and the study sites selected in this research are shown in Fig. 1.

\section{Sample Collection, Treatment, and Analysis}

Venous blood and spot urine samples were taken from 30 subjects in May and June (2005 and 2006). During the same period, 56 samples of drinking well water were taken from all three communities. During two consecutive months (May and June) in the third year (2007), 34 samples of well water and 36 blood, spot urine, and hair samples were taken from 17 subjects from the Ćelije and Draž communities. Wells were selected randomly within this region.

\section{Drinking Well Water Sample Collection and Sample Treatment}

During sampling of the well water, the water was allowed to leak from the tap for about 60 seconds or it was taken from the container, and then it was sampled in $100-\mathrm{mL}$ polyethylene bottles. After that, $1 \mathrm{~mL}$ of $33 \%$ nitric acid was added in each and then the bottles were shaken vigorously. The samples of well water were placed in a freezer at $-20^{\circ} \mathrm{C}$ [27]. The same procedure was done within a week in all three local communities, and after that all drinking well water samples were transported in a portable freezer to the laboratory for analyses.

\section{Biological Sample Collection and Sample Treatment}

Sampling of blood and urine tests was done by a laboratory technician. A blood sample of at least $3 \mathrm{~mL}$ was obtained from each subject using a Vacuette Blood Collection Needle $(38 \times 0.9 \mathrm{~mm})$, and Vacuette Serum Gel Tube $3.5 \mathrm{~mL}$ (Greiner Bio-One, Kremsmünster, Austria). Serum was separated from the blood on the same day (Microtubes 3810X, $1.5 \mathrm{~mL}$, Eppendorf Geratebau, Hamburg, Germany). Spot urine samples were also collected from each subject by a laboratory technician, and placed in urine collection containers $(55 \mathrm{~mL}$, Plastika Moćan, Samobor, Croatia). A hair sample approximately $0.1 \mathrm{~cm}$ wide and $3 \mathrm{~cm}$ long was taken from the occipital 


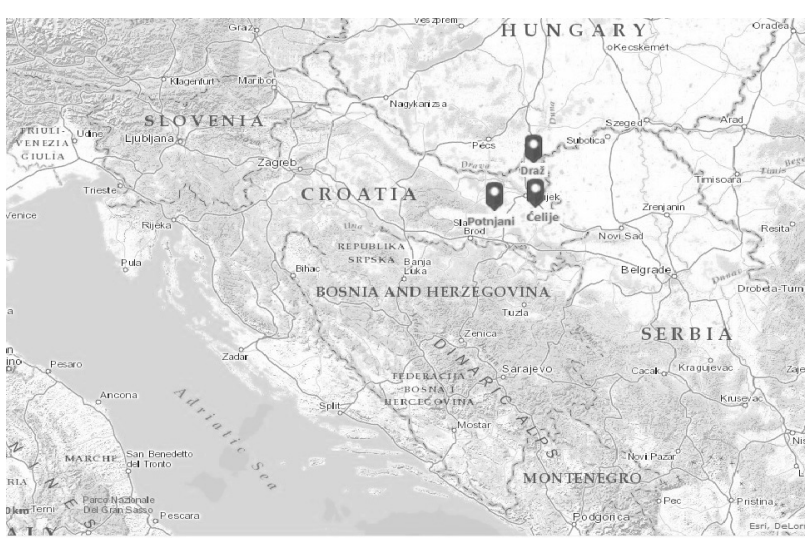

Fig. 1. Map of Croatia with study sites Draž, Ćelije, and Potnjani marked with dark arrows.

part of the head of each subject, adjacent to the scalp, using stainless steel scissors and placed into polyethylene bags. If the hair was short, several samples from the same part of the head were taken. After completing the collection, biological samples (serum and urine) were stored in a freezer at $-70^{\circ} \mathrm{C}$ [27]. The same procedure was done within a week in all three local communities, and then all biological samples were transported in a portable freezer to the laboratory for analysis.

\section{Trace Analysis by Inductively Coupled Plasma Mass Spectrometry}

Complete analysis of the drinking water and biological samples was performed using inductively coupled plasma mass spectrometry (Perkin Elmer, ELAN DRC-e) in the Laboratory of General and Inorganic Chemistry, Faculty of Chemical Engineering and Technology, University of Zagreb. Approximately $10 \mathrm{~mL}$ of thawed water samples (conditioned 24 hours at laboratory temperature) were taken for the analysis. The serum and urine samples were thawed, acidified with $60 \%$ nitric acid $(0.1 \mathrm{~mL} / 10 \mathrm{~mL}$ of sample), well mixed, and then $0.5 \mathrm{~mL}$ of them diluted to $10 \mathrm{~mL}$ with $1 \%(\mathrm{v} / \mathrm{v})$ nitric acid before analysis [28]. The hair samples were washed with acetone and air dried 24 hours. Approximately $0.1 \mathrm{~g}$ of it was weighed, dissolved in $1 \mathrm{~mL}$ of nitric acid, and diluted to $12 \mathrm{~mL}$ for analysis. High purity nitric acid ("Suprapure," Merck) was used throughout. Determination of the elements investigated was performed according to U.S. EPA method 200.8 [29]. The instrument was calibrated after every $12^{\text {th }}$ sample using external standard "71-Element Group Multi Element Standard Solution" (Inorganic Ventures, USA) and internal standards with the elements yttrium (Y), indium (In), terbium (Tb), and bismuth (Bi) (Inorganic Ventures, USA). The analytical methods were validated using standard reference materials: "ICP Multi Element Standard Solution X CertiPUR for Surface Water Testing” (Merck, Germany) and standard samples "Trace Elements Urine Blank" and "Trace Elements Urine” (SERO AS, Norway).

\section{Statistics}

Normality of distribution was tested by KolmogorovSmirnov test. Median and interquartile ranges were given for variables that were not normally distributed. Since the data were not normally distributed, Kruskal-Wallis test and Mann-Whitney U-test were used to determine the differences in the measured parameters among the three communities. The significance was set at $\alpha=0.05$.

\section{Results}

The levels of arsenic, copper, molybdenum, and selenium in the samples of drinking well water, urine, serum, and hair from the local communities in Eastern Croatia are shown in Table 1, and Figs 2, 3, 4, and 5.

The arsenic concentration differed significantly (Kruskal-Wallis test) in the samples of urine $(p<0.001)$, serum $(p=0.001)$, water $(p<0.001)$, and hair (MannWhitney test, $\mathrm{p}<0.001)$ taken from three localities (Table 1, Fig. 2). The arsenic concentration was significantly (Mann-Whitney test) higher in urine samples of subjects from Ćelije compared to the samples taken from Draž and Potnjani $(p<0.001)$, and from Draž compared to Potnjani $(p<0.001)$. In serum samples, concentration was higher (Mann-Whitney test, $p<0.001$ ) in subjects of Ćelije compared to Draž. In the samples of drinking water, higher concentration (Mann-Whitney test, $\mathrm{p}<0.001$ ) was in the Draž community compared to Ćelije and Potnjani. The higher concentration of arsenic in the hair (MannWhitney test, $\mathrm{p}<0.001$ ) was in subjects of Ćelije compared to Draž (Fig. 2).

The copper concentration differed significantly (Kruskal-Wallis test) in the samples of urine $(p<0.001)$, serum $(p=0.004)$, water $(p<0.001)$, and hair (MannWhitney test, $\mathrm{p}=0.004)$ taken from three localities (Table 1, Fig. 3). The copper concentrations were significantly (Mann-Whitney test) higher in urine samples of subjects from Draž compared to the samples taken from Ćelije $(p<0.001)$ and Potnjani $(p=0.036)$. In serum samples, concentration was higher (Mann-Whitney test, $\mathrm{p}<0.001$ ) in subjects of Draž compared to Ćelije. In the samples of drinking water, higher concentration (Mann-Whitney test, $\mathrm{p}<0.001$ ) was in Draž and Potnjani compared to Ćelije. The higher concentration of copper in the hair (MannWhitney test, $p=0.004$ ) was in subjects of Draž compared to Ćelije (Fig. 3).

The concentration of molybdenum differed significantly (Kruskal-Wallis test) in the samples of urine and water $(\mathrm{p}<0.001)$ taken from three localities (Table 1, Fig. 4). The molybdenum concentration was significantly (Mann-Whitney test) higher in urine samples of subjects from Draž compared to Ćelije $(\mathrm{p}=0.009)$ and Potnjani $(\mathrm{p}<0.001)$. In the samples of drinking water, higher concentration (Mann-Whitney test, $\mathrm{p}<0.001$ ) was in Draž compared to Ćelije and Potnjani (Fig. 4).

The concentration of selenium differed significantly (Kruskal-Wallis test) in the samples of urine, serum, 
Table 1. Basic measures and dispersions of parameters: biological tissues and drinking water in the local community.

\begin{tabular}{|c|c|c|c|c|}
\hline \multirow{3}{*}{ Parameters } & \multicolumn{3}{|c|}{ Local community } & \multirow{3}{*}{$\mathrm{p}^{\dagger}$} \\
\hline & \multirow{2}{*}{$\frac{\text { Ćelije }}{\mathrm{M}(25-75 \%)^{*}}$} & \multirow{2}{*}{$\frac{\text { Draž }}{\mathrm{M}(25-75 \%)^{*}}$} & \multirow{2}{*}{$\frac{\text { Potnjani }}{\mathrm{M}(25-75 \%)^{*}}$} & \\
\hline & & & & \\
\hline \multicolumn{5}{|c|}{ Arsenic } \\
\hline Urine $(\mu \mathrm{g} / \mathrm{L})$ & $65.7(39.5-112.6)$ & $11.6(25.79)$ & $0.05(0.05-12.5)$ & $<0.001$ \\
\hline Serum $(\mu \mathrm{g} / \mathrm{L})$ & $21.1(8.4-28.5)$ & $13.11(2.75-18.9)$ & $14.69(10.47-22.77)$ & 0.001 \\
\hline Water $(\mu \mathrm{g} / \mathrm{L})$ & $93.8(62.1-134.8)$ & $0.464(0.257-0.862)$ & $0.51(0.288-1.06)$ & $<0.001$ \\
\hline Hair $(\mu \mathrm{g} / \mathrm{g})$ & $1.72(1.22-3.27)$ & $0.136(0.095-0.176)$ & - & $<0.001^{*}$ \\
\hline \multicolumn{5}{|c|}{ Copper } \\
\hline Urine $(\mu \mathrm{g} / \mathrm{L})$ & $16.12(9.57-19.16)$ & $20.50(15.5-26.9)$ & $15.86(12.4-24.74)$ & $<0.001$ \\
\hline Serum $(\mu \mathrm{g} / \mathrm{L})$ & $937.4(771.7-1114.16)$ & $1058.8(943.4-1157.8)$ & 988.6 (859.7-1223.6) & 0.004 \\
\hline Water $(\mu \mathrm{g} / \mathrm{L})$ & $0.63(0.34-1.41)$ & $5.42(1.40-15.23)$ & $5.58(1.23-25.86)$ & $<0.001$ \\
\hline Hair $(\mu \mathrm{g} / \mathrm{g})$ & $8.64(8.1-9.74)$ & $11.69(9.72-12.85)$ & - & $\mathbf{0 . 0 0 4}$ \\
\hline \multicolumn{5}{|c|}{ Selenium } \\
\hline Urine $(\mu \mathrm{g} / \mathrm{L})$ & $7.61(0.05-23.31)$ & $25.79(11.68-37.42)$ & $3.47(0.05-16.36)$ & $<0.001$ \\
\hline Serum $(\mu \mathrm{g} / \mathrm{L})$ & $84.9(60.7-108.3)$ & $97.4(69.56-126.77)$ & $72.11(48.4-90.88)$ & $<0.001$ \\
\hline Water $(\mu \mathrm{g} / \mathrm{L})$ & $0.237(0.001-0.51)$ & $0.761(0.334-2.68)$ & $0.001(0.001-0.99)$ & $<0.001$ \\
\hline Hair $(\mu \mathrm{g} / \mathrm{g})$ & $0.33(0.274-0.39)$ & $0.406(0.307-0.445)$ & - & $0.146^{\ddagger}$ \\
\hline \multicolumn{5}{|c|}{ Molybdenum } \\
\hline Urine $(\mu \mathrm{g} / \mathrm{L})$ & $35.57(21,8-55,4)$ & $55.40(35.6-80.8)$ & $26.90(13.9-49.8)$ & $<0.001$ \\
\hline Serum $(\mu \mathrm{g} / \mathrm{L})$ & $1.28(1-1.65)$ & $1.38(1.17-1.75)$ & $1.30(1.05-1.54)$ & 0.294 \\
\hline Water $(\mu \mathrm{g} / \mathrm{L})$ & $0.012(0.001-0.39)$ & $0.24(0.11-0.59)$ & $0.001(0.001-0.012)$ & $<0.001$ \\
\hline Hair $(\mu \mathrm{g} / \mathrm{g})$ & $0.05(0.037-0.08)$ & $0.05(0.04-0.07)$ & - & $0.868^{\ddagger}$ \\
\hline
\end{tabular}

*Median (interquartile range), ${ }^{\dagger}$ Kruskal Wallis test, ${ }^{*}$ Mann Whitney test

and water $(\mathrm{p}<0.001)$ taken from three localities (Table 1, Fig. 5). The selenium concentration was significantly (Mann-Whitney test) higher in urine samples of subjects from Draž compared to Ćelije and Potnjani $(\mathrm{p}<0.001)$. In serum samples, concentration was higher (Mann-Whitney test) in subjects of Draž compared to Ćelije $(p=0.005)$ and Potnjani $(p<0.001)$, and from Potnjani compared to Ćelije ( $\mathrm{p}=0.012)$. In the samples of drinking water, higher concentration (Mann-Whitney test) was in Draž compared to Ćelije $(\mathrm{p}<0.001)$ and Potnjani $(\mathrm{p}=0.004)$. All the data are presented in Fig. 5.

\section{Discussion}

\section{Arsenic}

Determining arsenic in drinking water and biological tissues is very important because of the insight into the level of human exposure to this element. Population in the rural areas is particularly sensitive because of their low socio-economic and educational status $[8,30]$. The concentrations of arsenic in groundwater vary considerably among different countries [4, 31, 32]. Even in the same district, arsenic concentrations may vary significantly [33]. In the Pannonian Basin (Hungary, Romania, Croatia, and Serbia), groundwater resources have naturally high levels of arsenic, which makes it the largest region in Europe that is affected by high concentrations of this element in drinking water. Roughly 1 million people are exposed to concentrations of arsenic in their drinking water that are above the EU maximum admissible level of $10 \mu \mathrm{g} / \mathrm{L}$ [34]. In eastern Croatia, which is also part of the Pannonian Basin, groundwater is contaminated with arsenic. In the study of Ujevićet et al. [35], arsenic was detected in 46 out of 56 groundwater samples, with the highest arsenic concentration up to $461 \mu \mathrm{g} / \mathrm{L}$. In another study, which was conducted in eastern Croatia by Romić et al. [36], groundwater samples taken from the water wells that supply the town of Osijek with drinking water showed a mean arsenic concentration of $240 \mu \mathrm{g} / \mathrm{L}$. Ćavar et al. [37] conducted a study at four locations in eastern Croatia, and recorded various mean concentrations of arsenic in drinking water of 0.14 to $611.89 \mu \mathrm{g} / \mathrm{L}$, while in 
a)

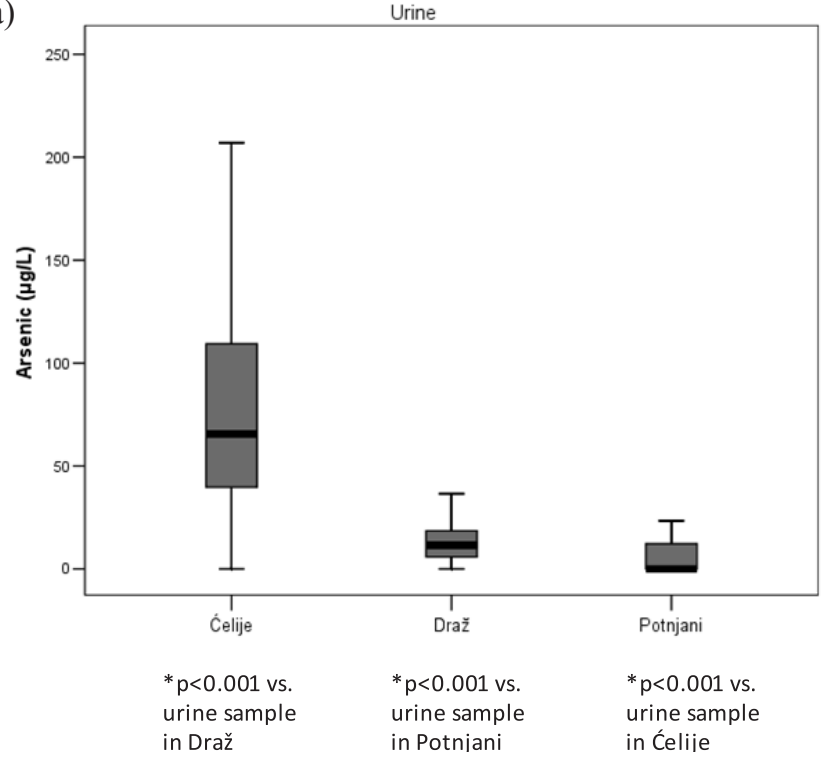

c)

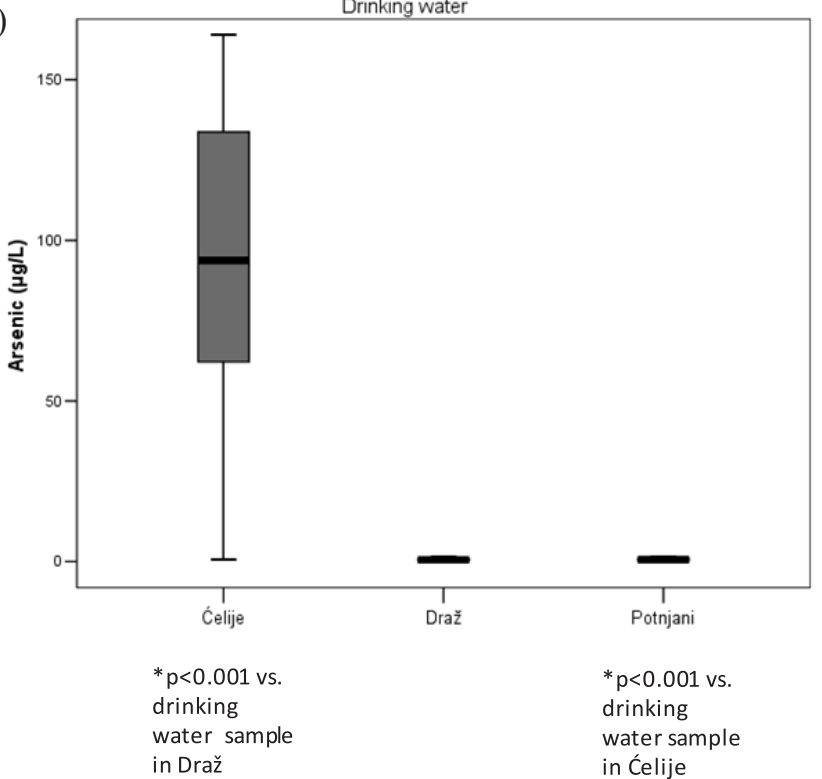

b)

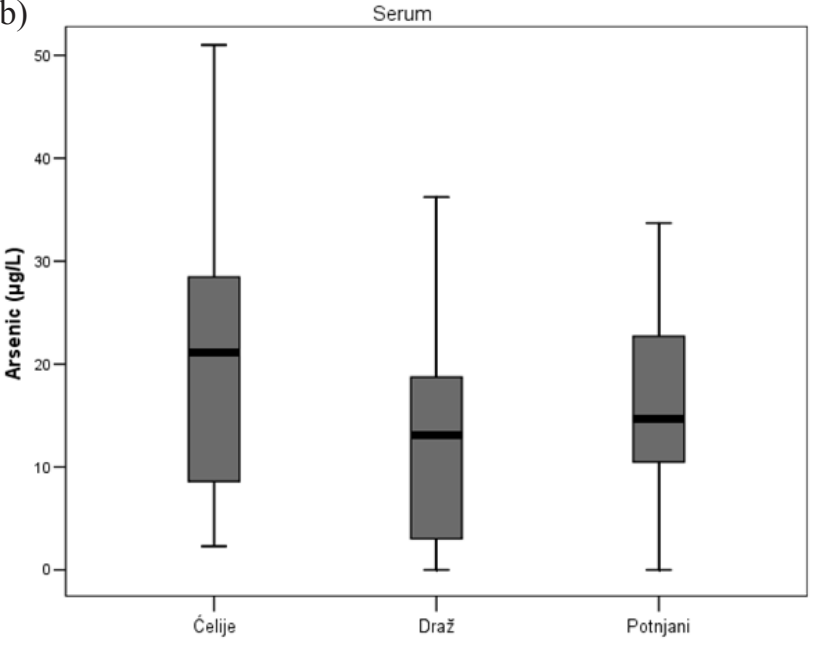

$* p<0.001$ vs.

serum sample

in Draž

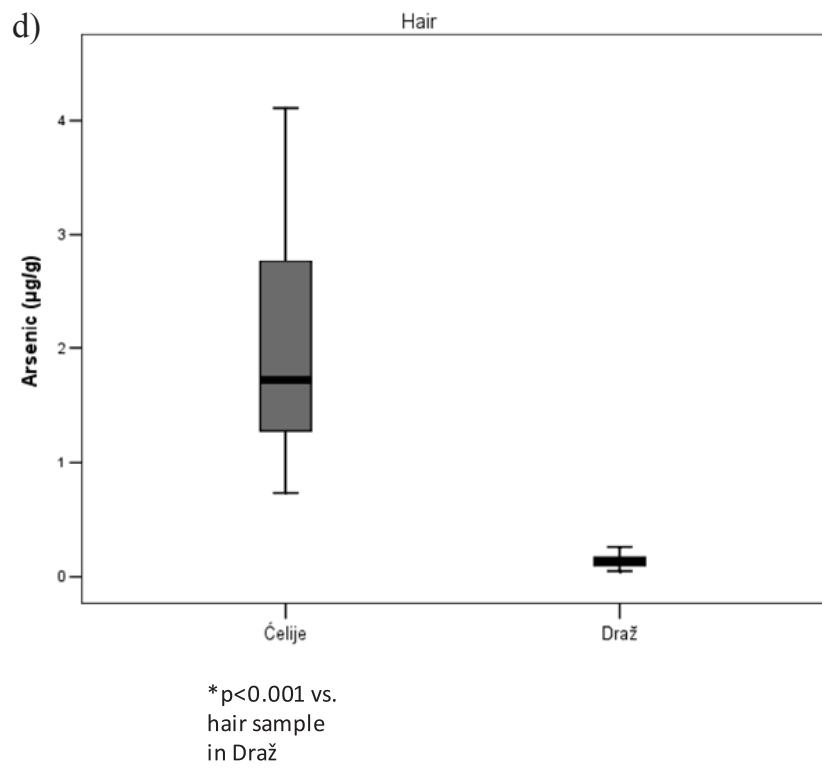

Fig. 2. Arsenic concentrations (median) in: a) urine, b) serum, c) drinking water ( $\mu \mathrm{g} / \mathrm{L})$, and d) hair samples ( $\mu \mathrm{g} / \mathrm{g}$ ) from Ćelije, Draž, and Potnjani.

another study by Habuda-Stanić et al. [38] (also in eastern Croatia) the concentrations of arsenic in drinking water were in the range 10 to $610 \mu \mathrm{g} / \mathrm{L}$.

In our study, exposure to arsenic in drinking water varied. The highest mean arsenic concentration in drinking water was found in Ćelije $(93.8 \mu \mathrm{g} / \mathrm{L})$, significantly exceeding the $\mathrm{EU}$, WHO, and Croatian maximum admissible level of $10 \mu \mathrm{g} / \mathrm{L}$, while in the other two communities mean arsenic concentrations in drinking water were far below that level [39-41].

For biomonitoring it is necessary to analyze arsenic in biological tissues. Arsenic levels in blood and urine have a short biological half-life and reflect recent exposure, and in the case of arsenic in blood, it lasts only for a few hours. Speciation of the arsenic species is mandatory for correct interpretation of the data. Arsenic concentration in urine mainly reflects recent exposure. In Europe the arsenic concentration in urine of non-exposed individuals is about $10 \mu \mathrm{g} / \mathrm{L}$, whereas in Japan it is $50 \mu \mathrm{g} / \mathrm{L}$ or higher [42]. In Vietnam, where the population has been exposed to arsenic in groundwater (arsenic levels ranged from $<1.8$ to $486 \mu \mathrm{g} / \mathrm{L}$ ) and rice had a positive correlation between the arsenic concentration in urine and the estimated arsenic intake [43]. In a population with skin disorders (melanosis and keratosis) there is a good correlation between the concentration of arsenic in drinking water and its concentration in biological tissues and hair. Arsenic concentration in drinking water was in the range from $35.2 \mu \mathrm{g} / \mathrm{L}$ to $152 \mu \mathrm{g} / \mathrm{L}$, and concentrations in scalp hair and blood were above the permissible values $0.034-0.319 \mu \mathrm{g} / \mathrm{g}$ for hair and $<0.5-4.2 \mu \mathrm{g} / \mathrm{L}$ for blood [44]. In a study conducted by Gault et al. [45] on a small population demonstrated a positive correlation between the concentration of arsenic in drinking water 
a)

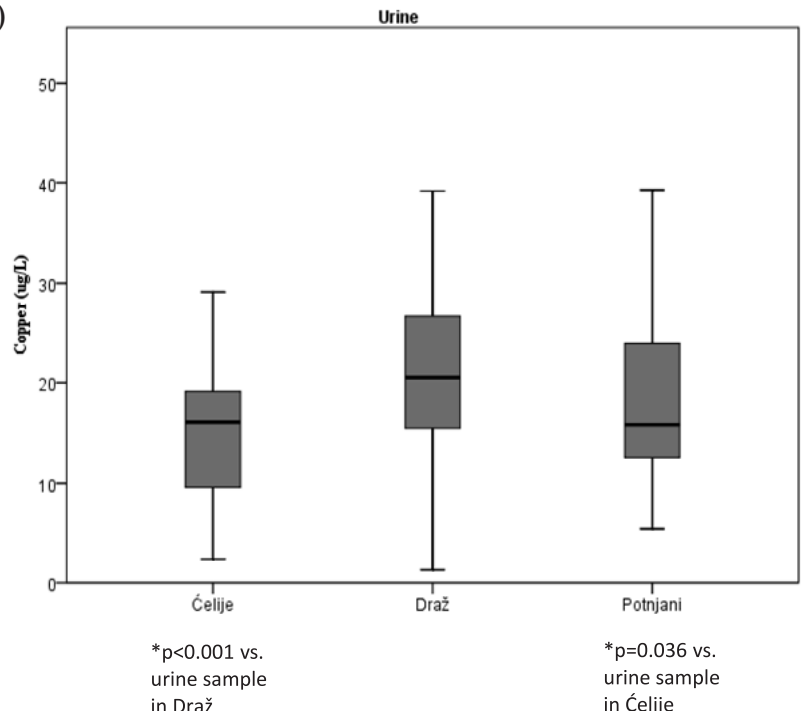

c)

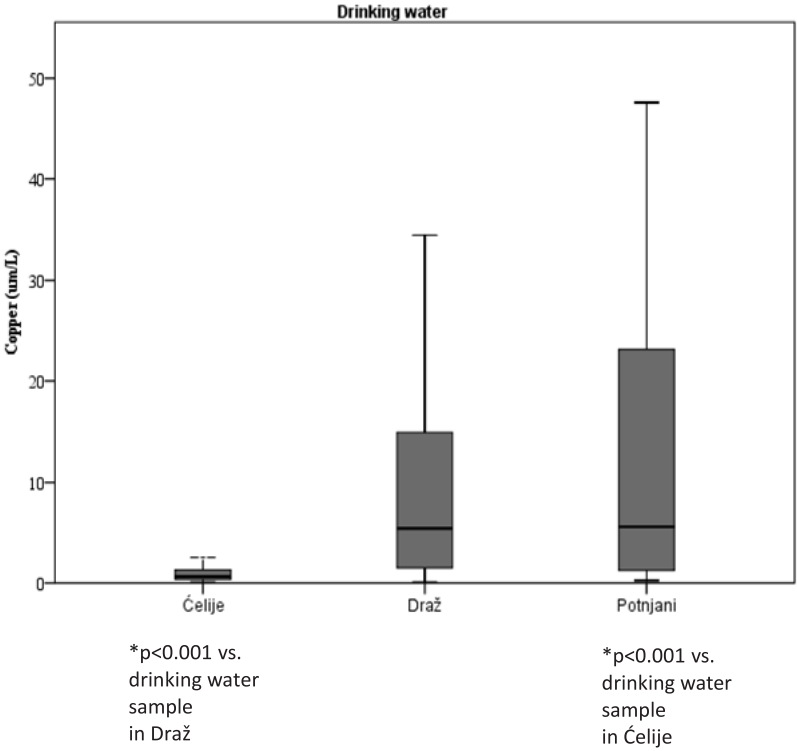

b)

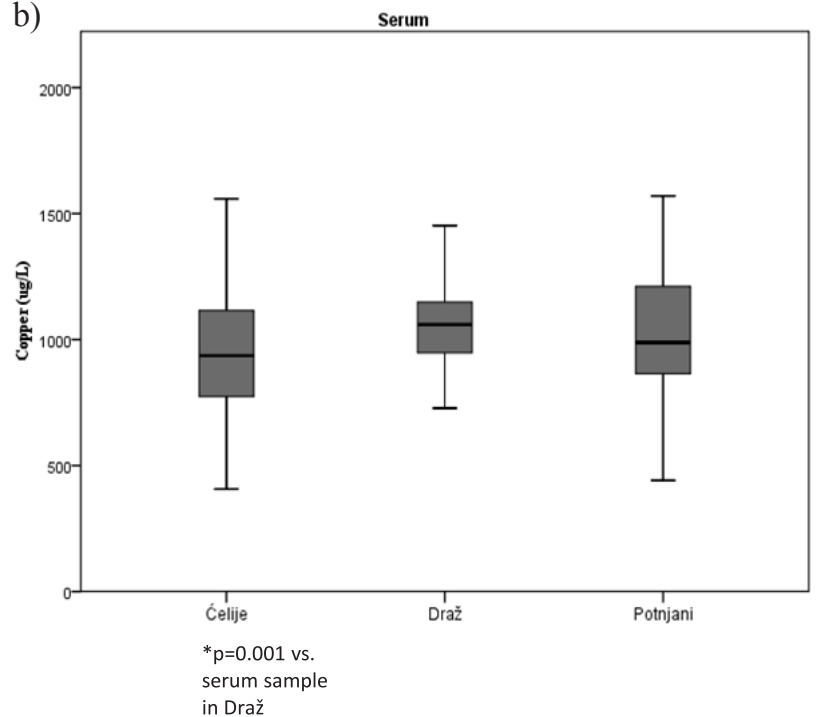

d)

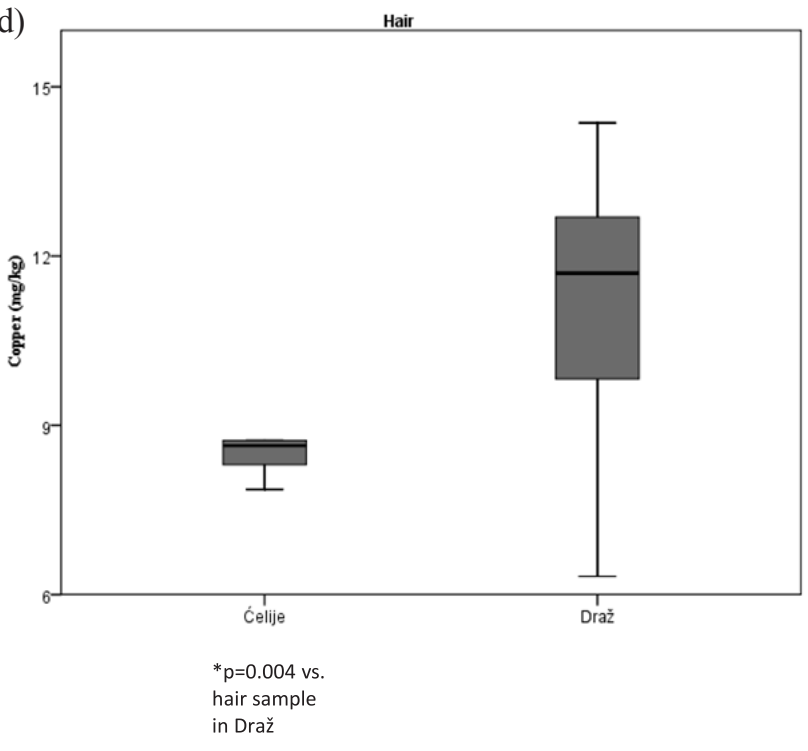

Fig. 3. Copper concentrations (median) in: a) urine,b) serum,c) drinking water $(\mu \mathrm{g} / \mathrm{L})$, and d) hair samples (mg/kg) from Ćelije, Draž, and Potnjani.

$(0.21-943 \mu \mathrm{g} / \mathrm{L})$ and its concentrations in hair and nails. In these subjects, arsenic concentrations in hair ranged from 0.10 to $7.95 \mu \mathrm{g} / \mathrm{g}$, and in many it exceeded baseline levels [45].

Mandal et al. [46] showed that there is a positive correlation between the consumption of drinking water contaminated with arsenic and the concentrations of arsenic in urine, hair, and nails, indicating that any of these measurements could be a biomarker of exposure. While the concentrations of arsenic in urine and hair require speciation of arsenic, total arsenic concentrations in fingernails do not require its speciation. In the study of Samanta et al. [47] mean arsenic concentrations in the hair collected in populations from arsenic-affected areas in India was $2.29 \mu \mathrm{g} / \mathrm{g}$. Reference values for arsenic are in the whole blood $5 \mu \mathrm{g} / \mathrm{L}$, serum $3.5 \mu \mathrm{g} / \mathrm{L}$, hair $0.26 \mu \mathrm{g} / \mathrm{g}$, and urine $20 \mu \mathrm{g} / \mathrm{L}$ [48]. Reference levels for arsenic in the urine of a healthy Italian (European Union) population are in the range 2.3-31.1 $\mu \mathrm{g} / 1$ and in blood 0.4-11.9 $\mu \mathrm{g} / \mathrm{L}$ [49].

Another study conducted in eastern Croatia also showed a significant correlation between the amount of arsenic in the hair and its elevated concentrations in drinking water, where higher concentrations of arsenic in drinking water led to higher concentrations in the hair [38]. Our results showed that in Ćelije, arsenic content in the groundwater for drinking purposes $(93.8 \mu \mathrm{g} / \mathrm{L})$ was positively correlated with arsenic concentrations in serum $(21.1 \mu \mathrm{g} / \mathrm{L}, \mathrm{p}=0.001)$, urine $(65.7 \mu \mathrm{g} / \mathrm{L}, \mathrm{p}<0.001)$, and hair $(1.72 \mu \mathrm{g} / \mathrm{g}, \mathrm{p}<0.001)$. In all three biological samples (serum, urine, hair) from the Ćelije population, concentrations of arsenic were above the reference values for the EU population and the values determined by Iyengar and Woittiez [48], and Minoia et al. [49].

Hair can be a very good indicator for long-term exposure to arsenic in drinking water. Elevated concentrations of arsenic in the hair can be found for months after the arsenic 
a)

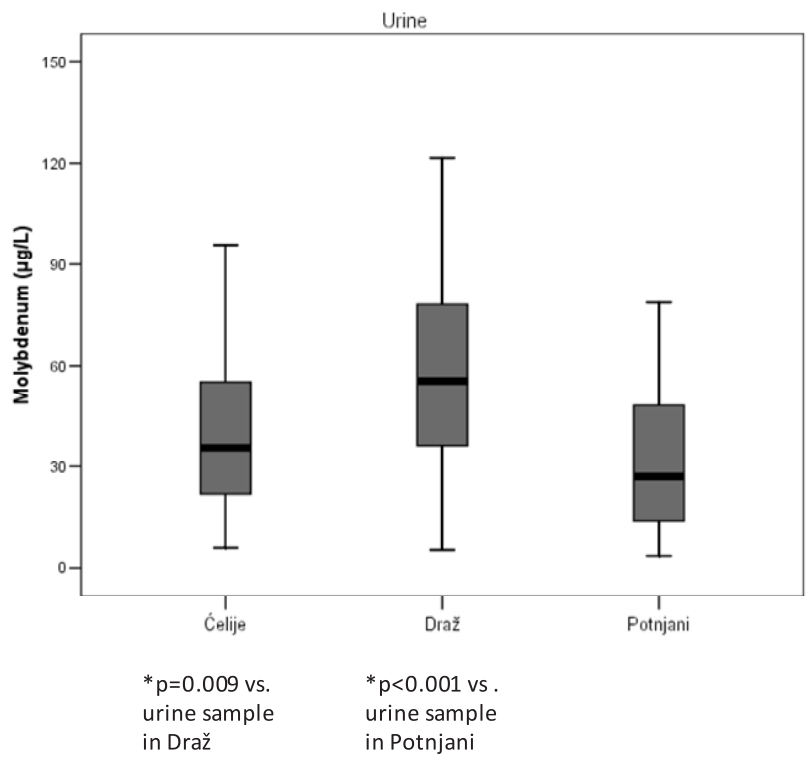

c)

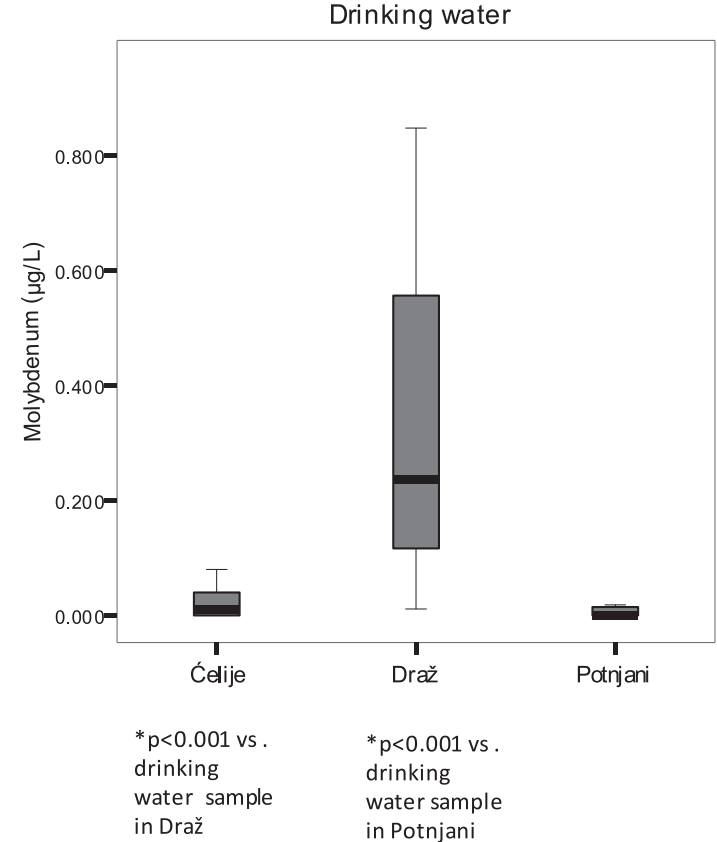

b)

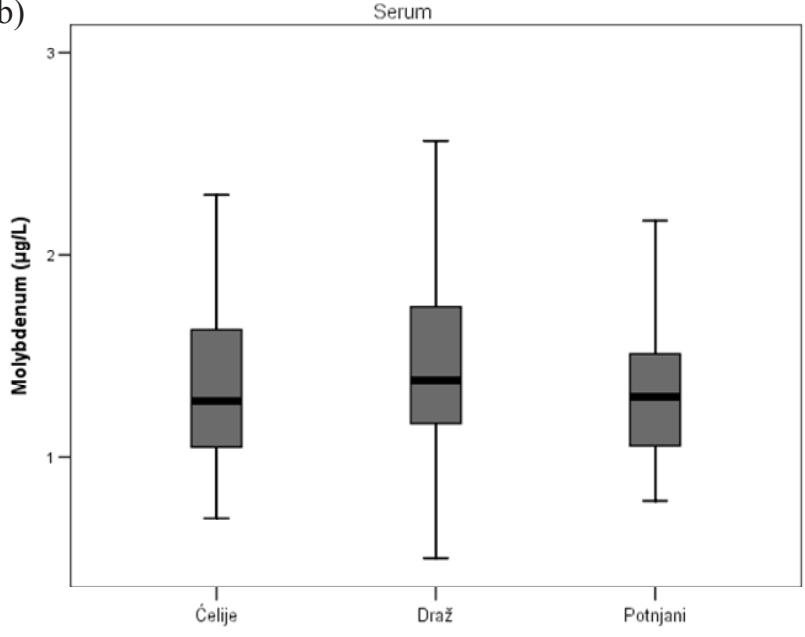

d)

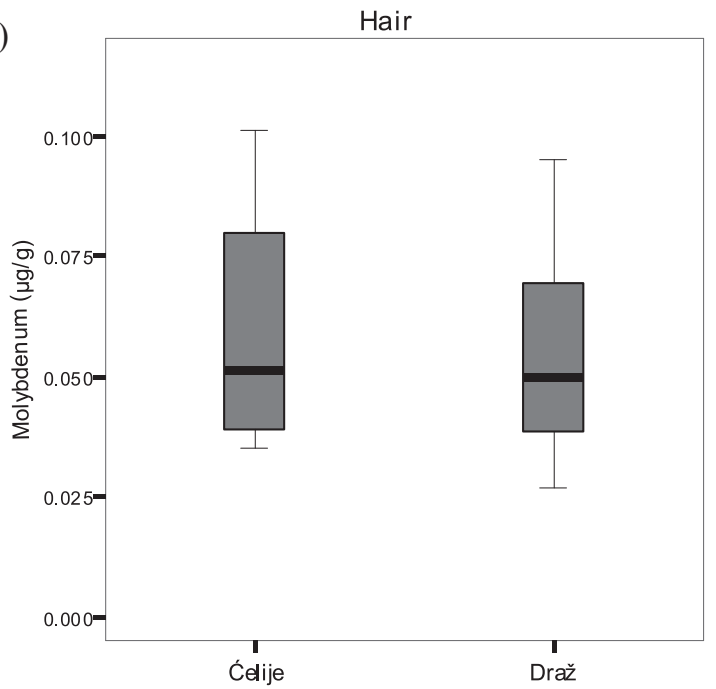

Fig. 4. Molybdenum concentrations (median) in: a) urine,b) serum,c) drinking water ( $\mu \mathrm{g} / \mathrm{L})$, and d) hair samples ( $\mu \mathrm{g} / \mathrm{g})$ from Ćelije, Draž, and Potnjani.

concentration in urine normalizes, but these results should be interpreted very cautiously because of the possibility of external contamination [50]. It is also worth mentioning that the concentration of arsenic in the serum and urine samples of Draž and Potnjani were significantly higher than in the drinking water. This means that arsenic found in the samples of serum and urine comes in small part from the water, and mostly from food and other sources.

\section{Copper}

Copper is an essential element for all living beings. Exposure to copper results almost exclusively from the ingestion of food and water [20]. Copper is very frequently found in groundwater or it can be introduced to tap water by corroding infrastructure [51]. Highly variable values of copper can be found in well water, which depends on the type of soil and the underlying water table. The concentration of copper in water of more than $5 \mathrm{mg} / \mathrm{L}$ leads to discoloration and a bitter taste [52]. Giriet et al. [53] showed that groundwater concentrations near two mining areas in India were 0.78-20.0 and $1.24-18.7 \mu \mathrm{g} / \mathrm{L}$. There are differences in the concentration of copper in drinking water between urban and nonurban areas (peripheral and rural). Higher concentrations of copper in drinking water have been reported in nonurban areas (peripheral $20 \mu \mathrm{g} / \mathrm{L}$ and rural $12 \mu \mathrm{g} / \mathrm{L}$ ), while in the urban areas lower concentrations $(8 \mu \mathrm{g} / \mathrm{L})$ have been reported. Contamination of water with copper after standing overnight in household pipes was similar in all 
a)

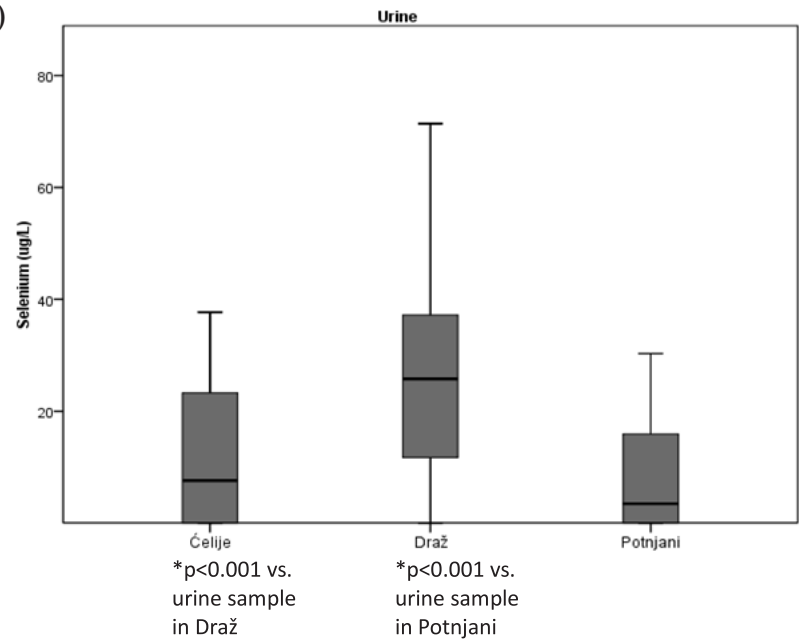

c)

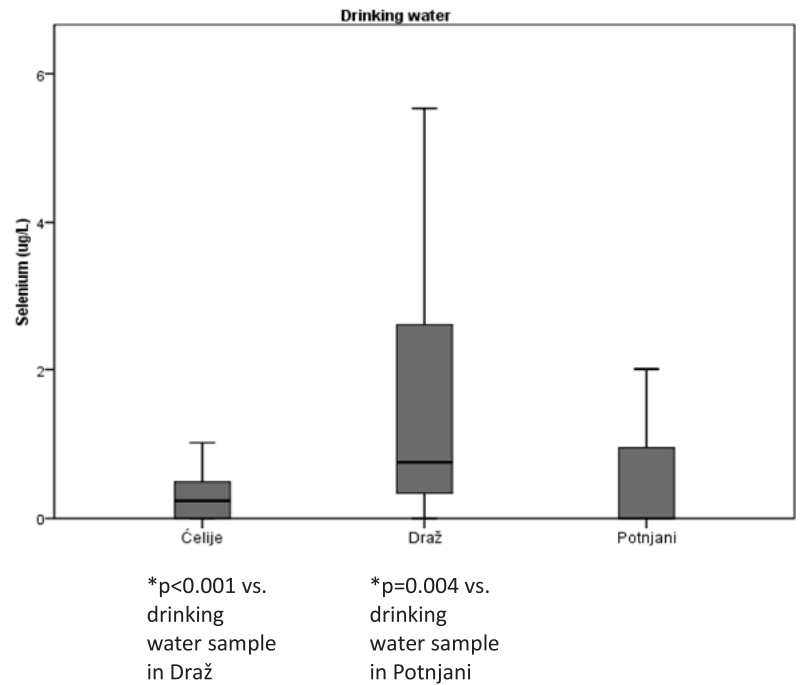

b)

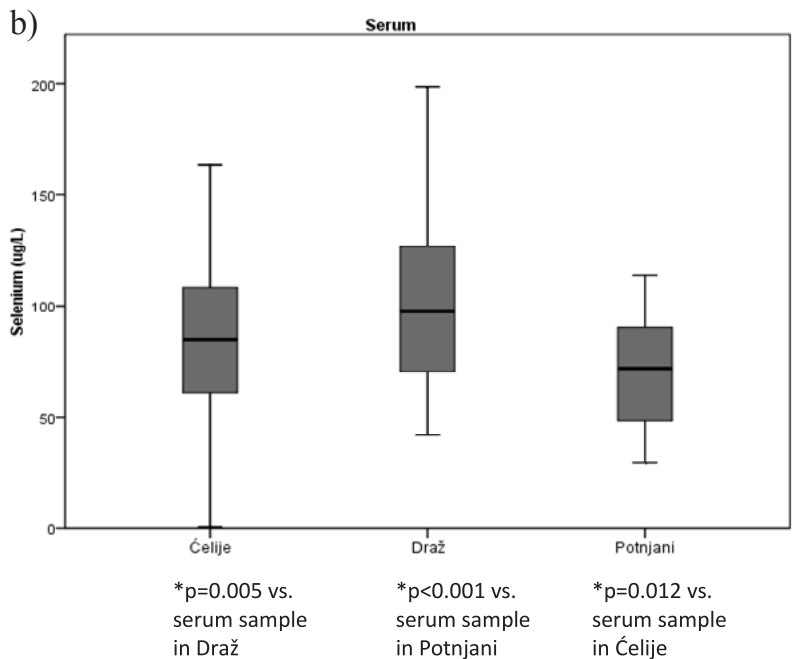

d)

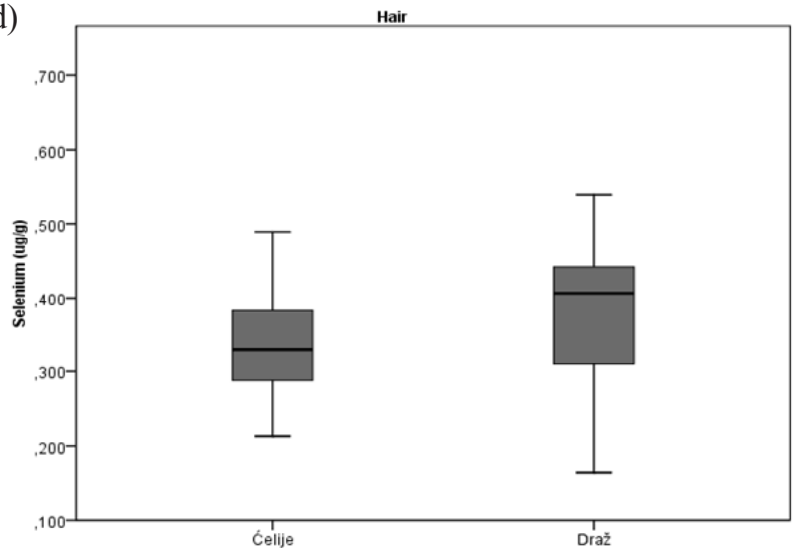

Fig. 5. Selenium concentrations (median) in: a) urine,b) serum,c) drinking water ( $\mu \mathrm{g} / \mathrm{L})$, and d) hair samples $(\mu \mathrm{g} / \mathrm{g})$ from Ćelije, Draž, and Potnjani.

three sites, with an average increase of about $20 \mu \mathrm{g} / \mathrm{L}$ [54]. One of the first cases of poisoning with copper from the public water system occurred in one family in the eastern U.S. state of Vermont. The concentration of copper in the drinking water was $7.8 \mathrm{mg} / \mathrm{L}$. It was suspected that the copper levels were elevated due to stagnation of water at the end of a copper main [55].

Various studies have shown that consumption of drinking water with a concentration of copper up to $2 \mathrm{mg} / \mathrm{L}$ does not cause gastrointestinal problems in infants, whereas in women only copper concentrations greater than $3 \mathrm{mg} / \mathrm{L}$ lead to an increase in gastrointestinal symptoms [20]. Drinking tap water with a concentration of copper of 5 and $6 \mathrm{mg} / \mathrm{L}$ leads to significantly more gastrointestinal symptoms compared to persons who consume water with a copper concentration of $<0.01 \mathrm{mg} / \mathrm{L}$. Both soluble (copper sulphate) and insoluble (copper oxide) copper can cause gastrointestinal symptoms [22, 56]. Trace amounts of copper in drinking water, less than one-tenth of that allowed in human drinking water by the U.S. Environmental Protection Agency, greatly enhanced an
Alzheimer's-like disease in an animal model. Healthy adults in the highest quintile of copper intake who also ate a high-fat diet lost cognition at over three times the normal rate $[57,58]$.

Median values for copper in drinking water in Draž and Potnjani were well below the maximal allowed concentration for copper of 2,000 and $1,300 \mu \mathrm{g} / \mathrm{L}$, according to Croatian regulations for the safety of drinking water or the WHO guideline value for copper, and the U.S. EPA [40, 41, 59]. In Ćelije median copper concentrations in drinking water were less than $1 \mu \mathrm{g} / \mathrm{L}$. Copper metabolism is homeostatically well controlled. Physiological (pregnancy) or pathological conditions (e.g., in some liver diseases) can influence the level of copper in the body. There seem to be no major methodological problems of evident contamination hazards associated with the measurement of copper in biological fluids. The copper concentration in serum or plasma of healthy individuals covers a range from 0.8 to $1.4 \mathrm{mg} / \mathrm{L}$. In urine the mean urinary concentration ranges from $15-36 \mu \mathrm{g} / 24 \mathrm{~h}$ [42]. Because of the lack of sensitive 
and specific indicators, serum copper concentration and ceruloplasmin are the most frequent indicators, but they only detect intense changes of copper status [60]. Despite limited data, serum copper appears to be a useful biomarker of copper status at the population level [61]. In the study of V. Iyengar, reference values in the whole-blood for copper ranged from $800-1,300 \mu \mathrm{g} / \mathrm{L}$, in serum from $800-1,750 \mu \mathrm{g} / \mathrm{L}$, in hair from $6.8-39 \mathrm{mg} / \mathrm{kg}$, and in urine from $12-80 \mu \mathrm{g} / \mathrm{L}$ [48]. Reference values for copper in urine in healthy Italians (EU) were 4.2-50 $\mu \mathrm{g} / \mathrm{L}$, for blood $807-1,643 \mu \mathrm{g} / \mathrm{L}$, and for serum (plasma) $601-1,373 \mu \mathrm{g} / \mathrm{L}$ [49]. In our study, the concentrations of copper in serum, urine, and hair in all three communities were within the reference range for the EU population and other published data $[48,49]$.

We are aware that in our study we did not examine the amount of copper that subjects intake through food and supplements containing copper. Higher values of copper in the serum and urine of all the subjects in relation to its value in drinking water in all three communities are probably caused in large part by copper intake through food and supplements containing copper or some other source of copper. However, we consider the significantly higher values of copper in urine, serum, and hair of the subjects in Draž compared to Ćelije to be partly caused by higher levels of copper in drinking water in Draž.

\section{Molybdenum}

The concentration of molybdenum in drinking water is usually less than $0.01 \mathrm{mg} / \mathrm{L}$, although concentrations as high as $200 \mu \mathrm{g} / \mathrm{L}$ have been reported near mining sites. A formal guideline value has not been set for molybdenum because it occurs in very low concentrations in drinking water. For guidance purposes, a health-based level is rounded to $0.07 \mathrm{mg} / \mathrm{L}$ [40]. Concentrations of molybdenum in surface water are more variable than in groundwater, but there is no evidence of notable seasonal effects. Molybdenum data for 1,398 groundwater samples from the British Geological Survey (BGS) groundwater database have a range of $<0.1-120 \mu \mathrm{g} / \mathrm{L}$, but with a 10-90 percentile range of $0.1-1.5 \mu \mathrm{g} / \mathrm{L}$ and a median of $0.12 \mu \mathrm{g} / \mathrm{L}$ [62]. In a study of drinking water from U.S. public systems noted concentrations of molybdenum in the range of 1-4 $\mu \mathrm{g} / \mathrm{L}$, while in another U.S. study molybdenum was detected in $30 \%$ of 3,676 analyzed samples in the range $<1-53 \mu \mathrm{g} / \mathrm{L}$ [62]. The Croatian regulations for the safety of drinking water did not set a maximum permissible concentration of molybdenum in drinking water [41]. Our results showed that the values of molybdenum in drinking water were well below the health-based level set by WHO [40].

Molybdenum can be measured in whole blood and serum. Concentrations in whole blood vary widely, although the mean concentration is $0.5 \mu \mathrm{g} / \mathrm{L}$ [24]. Plasma molybdenum reflects its low and high dietary intakes within 14 days and may be a useful indicator of low and high dietary intakes [63]. Molybdenum is very efficiently absorbed at all dietary molybdenum intakes [64]. In people, absorption of molybdenum after oral intake is in the range of $28-77 \%$ and urinary excretion is $17-80 \%$ of the total dose [65]. Molybdenum retention is regulated by urinary excretion. It is conserved at low intakes and excess molybdenum is rapidly excreted in the urine when intake is high $[64,66]$. Urinary levels of molybdenum can be affected by its levels in drinking water. Chappel et al. [67] showed that when the concentration of molybdenum in drinking water in individuals ranged 1-50 $\mu \mathrm{g} / \mathrm{L}$, its mean urinary level was $87 \mu \mathrm{g} / \mathrm{d}$, but when the concentration in drinking water was equal to or greater than $200 \mu \mathrm{g} / \mathrm{L}$, the mean urinary level of molybdenum was $187 \mu \mathrm{g} / \mathrm{d}$. In workers in smelters who were exposed to molybdenum in dust, high levels of molybdenum were present in the blood (up to $300 \mu \mathrm{g} / \mathrm{L}$ ) and urine (up to $11 \mathrm{mg} / \mathrm{L}$ ) [67].

Molybdenum concentration in the urine samples of subjects in Ćelije and Potnjani were very close to the reference value, while in Draž they were above the reference value [48]. Significantly higher median values of molybdenum in drinking water were measured in Draž compared to the other two communities. In Potnjani, molybdenum concentrations in drinking water were the lowest. Median values for molybdenum in serum samples from all three sites were not statistically significant. Higher median values for molybdenum in urine samples from the subjects in Draž rather than in the other two communities can be linked to the higher levels of molybdenum in drinking water in Draž. Molybdenum concentrations in hair did not show any statistically significant difference between the subjects in Ćelije and Draž.

\section{Selenium}

Selenium levels in seawater range from $0.06-0.12 \mathrm{pg} / \mathrm{L}$ and in the surface and groundwater they vary widely from $0.06-400 \mu \mathrm{g} / \mathrm{L}$. Levels of selenium in tap water samples from the public water supplies in the U.S., Canada, and Australia rarely exceed $10 \mu \mathrm{g} / \mathrm{L}$ [23]. In a study of 634 water wells in the U.S. state of Texas, only $4 \%$ of selenium observations exceeded the maximum contaminant level (MCL) for drinking water, and 19\% exceeded the recommended limit for irrigation water. Concentrations were considerably higher in relatively deep public supply and irrigation wells. Although human activity can affect selenium levels in drinking water, natural sources largely account for them [68]. Appreciable amounts of selenium in spring and well waters can be found due to geological occurrence. Concentrations of as much as 400-9,000 $\mu \mathrm{g} / \mathrm{L}$ have been reported in U.S. waters [69]. In a study of water samples from 129 wells in Mongolia, concentration of selenium was $0.7(<0.1-1.8 \mu \mathrm{g} / \mathrm{L})$ [70], while toxic concentrations $(45-341 \mu \mathrm{g} / \mathrm{L})$ were found in groundwater in northwest India [71].

The provisional guideline value for selenium is $40 \mu \mathrm{g} / \mathrm{L}$. It is provisional because of the uncertainties inherent in the scientific database. Most drinking water contains concentrations of selenium that are significantly lower than $10 \mu \mathrm{g} / \mathrm{L}$, except in certain seleniferous areas 
[40]. Chronic ingestion of $850 \mu \mathrm{g} /$ day has been associated with toxicity [50]. In our study, for all three communities the concentration of selenium in drinking water did not exceed $10 \mu \mathrm{g} / \mathrm{L}$, which is the maximum permissible concentration for selenium in drinking water set by Croatian regulation for safety on drinking water [41]. Selenium can be measured in the blood, hair, and urine [50]. There is considerable geographical variation in the concentration of selenium in the whole blood; the range for the United Kingdom (UK) is 0.091 to $0.120 \mu \mathrm{g} / \mathrm{mL}$ [24]. Whole blood levels remain elevated longer than serum levels (which are typically 40-60\% lower) and may reflect long-term exposure. In a normal diet, whole blood selenium levels range from 0.1 to $0.2 \mathrm{mg} / \mathrm{L}$. Average hair levels are up to $0.5 \mathrm{ppm}$. The utility of hair testing is complicated by the widespread use of selenium in shampoos. Both whole blood and urinary concentrations reflect dietary intake. Overexposure should be considered when blood selenium levels exceed $0.4 \mathrm{mg} / \mathrm{L}$ or urinary excretion exceeds $600-1,000 \mu \mathrm{g}$ /day [50]. In adolescent girls in Iceland, mean whole blood selenium was $117 \pm 12 \mu \mathrm{g} / \mathrm{L}$ (range $90-208$ ); nearly $90 \%$ of subjects were above the optimal level of $100 \mu \mathrm{g} / \mathrm{L}$ [72].

Our results showed that the values of selenium in the samples of serum and urine in all three communities were within reference values except for a lower value of selenium in urine samples in Potnjani [48]. Significantly higher concentrations of selenium in drinking water were measured in Draž compared to Ćelije and Potnjani. Higher concentrations of selenium in serum and urine samples were measured in Draž compared to Ćelije and Potnjani. The higher concentrations of selenium in the samples of serum and urine of subjects in Draž compared to Ćelije and Potnjani can be partially linked to the higher concentration of selenium in drinking water in Draž. There was no statistically significant difference in the selenium concentrations in hair samples.

\section{Conclusion}

In our study, significantly higher concentrations of arsenic (median $93 \mu \mathrm{g} / \mathrm{L}$ ) in drinking water was measured in Ćelije, while in the other two communities the concentrations of arsenic in drinking water were negligible. A significantly higher concentration of arsenic in biological tissues was also measured in the participants from the community of Ćelije, compared to the other two communities, which can be linked to higher arsenic concentrations in drinking water in that community. For more accurate information, arsenic speciation should be done. The concentrations of copper, molybdenum, and selenium in drinking water at all three studied sites were below the values that are prescribed by the WHO Guidelines for drinking-water quality (2011) and Croatian regulations for the safety of drinking water. Significantly higher values of selenium in the serum and urine in Draž compared to Ćelije and Potnjani are partly caused by higher levels of selenium in drinking water in that community.
Higher median values for molybdenum in the urine samples from the Draž population than in the other two communities can be linked to the higher levels of molybdenum in Draž drinking water. Significantly higher levels of copper in all three biological specimens in the Draž participants may be partially attributed to the higher levels of copper in its drinking water compared to Ćelije. Physiological parameters were not taken into account and had no role in the interpretation of research results.

\section{Acknowledgements}

This study was designed with the help of Professor Laszlo Sipos PhD from the Faculty of Chemical Engineering and Technology, University of Zagreb, Croatia, and Professor Dinko Puntarić MD, PhD from the Department of Public Health, Josip Juraj Strossmayer University of Osijek, Croatia. Significant contributions to the implementation of our study were made by the laboratory staffs of Health Center Osijek and the University Hospital Osijek. The authors thank all participants in the investigated areas of Eastern Slavonia and Baranja who directly participated in this study, as well as everyone who was indirectly involved in this study.

\section{References}

1. GARELICK H., JONES H., DYBOWSKA A, VALSAMIJONES E. Arsenic pollution sources. Rev Environ Contam Toxicol. 197, 17, 2008.

2. RAHMAN M.M., NG J.C., NAIDU R. Chronic exposure of arsenic via drinking water and its adverse health impacts on humans. Environ Geochem Health. 1, 189, 2009.

3. POKHREL D., BHANDARI B.S., VIRARAGHAVAN T. Arsenic contamination of groundwater in the Terai region of Nepal: an overview of health concerns and treatment options. Environ Int. 35, 157, 2009.

4. YADAY I.C., SINGH S., DEVI N.L., MOHAN D., PAHARI M., TATER P.S., SHAKYA B.M. Spatial distribution of arsenic in groundwater of southern Nepal. Rev Environ Contam Toxicol. 218, 125, 2012.

5. LAN C.C., YU H.S., KO Y.C. Chronic arsenic exposure and its adverse health effects in Taiwan: a paradigm for management of a global environmental problem. Kaohsiung J Med Sci. 27, 411, 2011.

6. KIM K.W., CHANPIWAT P., HANH H.T., PHAN K., STHIANNOPKAO S. Arsenic geochemistry of groundwater in Southeast Asia. Front Med. 5, 420, 2011.

7. GUHA MAZUMDER D.N. Chronic arsenic toxicity \& human health. Indian J Med Res. 128, 436, 2008.

8. SANCHA A.M., O'RYAN R. Managing hazardous pollutants in Chile: arsenic. Rev Environ ContamToxicol. 196, 123, 2008.

9. VAHIDNIA A., van der Voet G.B., de WOLFF F.A. Arsenic neurotoxicity-a review. Hum Exp Toxicol. 26, 823, 2007.

10. GUHA MAZUMDER D., DASGUPTA U.B. Chronic arsenic toxicity: studies in West Bengal, India. Kaohsiung J Med Sci. 27, 360, 2011.

11. RUIZ de LUZURIAGA A.M., AHSAN H., SHEA C.R. Dermatol Clin. 29, 45, 2011. 
12. SMITH A.H., STEINMAUS C.M. Health effects of arsenic and chromium in drinking water: recent human findings. Annu Rev Public Health. 30, 107, 2009.

13. BARRON E., MIGEOT V., RABOUAN S., POTINGAUTIER M., SEBY F., HARTEMANN P., LEVI Y., LEGUBE B. The case for re-evaluating the upper limit value for selenium in drinking water in Europe. J Water Health. 7, 630, 2009.

14. PORTER R.S., KAPLAN J.L. The Merck Manual of Diagnosis and Therapy, $19^{\text {th }}$ ed.;Merck SHARP \& DOME CORP.: Whitehouse Station, 47, 2011.

15. OLIVARE M., UAUY R. Copper as an essential nutrient. Am J Clin Nutr. 63, 791, 1996.

16. BREWER G.J. The risks of free copper in the body and the development of useful anticopper drugs. Curr Opin Clin Nutr Metab Care. 11, 727, 2008.

17. LI S., XIAO T., ZHENG B. Medical geology of arsenic, selenium and thallium in China. Sci Total Environ. 421-422, 31, 2012

18. BARCELOUX D.G. Molybdenum. J Toxicol Clin Toxicol. 37, 231, 1999.

19. NOVOTNY J.A., TURNLUND J.R. Molybdenum intake influences molybdenum kinetics in men. J Nutr, 137, 37, 2007.

20. PIZARRO F., OLIVARES M., GIDI V., ARAYA M. The gastrointestinal tract and acute effects of copper in drinking water and beverages. Rev Environ Health, 14, 231, 1999.

21. SADHRA S.S., WHEATLEY A.D., CROSS H.J. Dietary exposure to copper in the European Union and its assessment for EU regulatory risk assessment. 374, 223, 2007.

22. PIZARRO F., OLIVARES M., ARAYA M., GIDI V., UAUY R. Gastrointestinal effects associated with soluble and insoluble copper in drinking water. Environ Health Perspect, 109, 949, 2001.

23. NORDBERG G.F., FOWLER B.A., NORDBERG M., FRIBERG L. Handbook on the toxicology of metals, 3rd ed.; Academic Press: Burlington, 733, 2007.

24. WEBSTER-GANDY J., MADDEN A., HOLDSWORTH M. Oxford handbook of nutrition and dietetics, $1^{\text {st }}$ ed.; Oxford University Press: New York, 142, 2006.

25. BARRON E., MIGEOT V., SEBY F., INGRAND I., POTINGAUTIER M., LEGUBE B., RABOUAN S. Selenium exposure in subjects living in areas with high selenium concentrated drinking water: results of a French integrated exposure assessment survey. Environ Int. 40, 155, 2012.

26. MOMCILOVIC B. A case report of acute human molybdenum toxicity from a dietary molybdenum supplement-a new member of the "Lucor metallicum" family. Arh Hig Rada Toksikol. 50, 289, 1999.

27. NURNBERG HW., MART L., RUTZEL H., SIPOS L. Investigations of distribution of heavy metals in the Atlantic and Pacific Oceans. Chemical Geology, 40, 97, 1983.

28. NAKAGAWA J., TSUCHIYA Y, YASHIMA Y., TEZUKA M., FUJIMOTO Y. Determination of trace levels of elements in urine by inductively coupled plasma mass spectrometry. Journal of Health Science. 50, 164, 2004.

29. WOLF R.E., DENOYER E., GROSSER Z. US EPA method 200.8 for the analysis drinking waters and wastewaters, Parkin Elmer Inc., 2001. Application Note ENVA-300B.

30. MAZUMDER D.N., GHOSH A., MAJUMDAR K.K., GHOSH N., SAHA C., MAZUMDER R.N. Arsenic contamination of ground water and its health impact on population of district of nadia, west bengal, India. Indian $\mathrm{J}$ Community Med. 35, 331, 2010.

31. CHAKRABORTI D., DAS B., RAHMAN M.M., CHOWDHURY U.K., BISWAS B., GOSWAMI A.B.,
NAYAK B., PAL A., SENGUPTA M.K., AHAMED S., HOSSAIN A., BASU G., ROYCHOWDHURY T., DAS D. Status of groundwater arsenic contamination in the state of West Bengal, India: a 20-year study report. Mol Nutr food Res. 53, 542, 2009.

32. MAITY J.P., NATH B., CHEN C.Y., BHATTACHARYA P., SRACEK O., BUNDSCHUH J., KAR S., THUNVIK R., CHATTERJEE D., AHMED K.M., JACKS G., MUKHERJEE A.B., JEAN J.S. Arsenic-enriched groundwaters of India, Bangladesh and Taiwan-comparison of hydrochemical characteristics and mobility constraints. J Environ Sci Health A Tox Hazard Subst Environ Eng, 46, 1163, 2011.

33. KHAN M.M., SAKAUCHI F., SONODA T., WASHIO M., MORI M. Magnitude of arsenic toxicity in tube-well drinking water in Bangladesh and its adverse effects on human health including cancer: evidence from a review of the literature. Asian Pac J Cancer Prev. 4, 7, 2003.

34. ROWLAND H.A.L., OMOREGIE E.O., MILLOT R., JIMENEZ C., MERTENS J. M., BACIU C., HUG S.J., BERG M. Geochemistry and arsenic behaviour in groundwater resources of the Pannonian Basin (Hungary and Romania). Applied Geochemistry, 26, 1, 2011.

35. UJEVIĆ M., DUIĆ Ž., CASIOT C., SIPOS L., SANTO V., DADIĆ Ž, HALAMIĆ J. Occurence and geochemistry of arsenic in the groundwater of Eastern Croatia. Applied Geochemistry, 25, 1017, 2010.

36. ROMIĆ Ž., HABUDA-STANIĆ M., KALAJDŽIĆ B., KULES M. Arsenic distribution, concentration and speciation in groundwater of the Osijek area, eastern Croatia. Applied Geochemistry, 26, 37, 2011.

37. CAVAR S., KLAPEC T., GRUBESIC R.J., VALEK M. High exposure to arsenic from drinking water at several localities in eastern Croatia. Sci Total Environ, 339, 277, 2005

38. HABUDA-STANIĆ M., KULEŠ M., KALAJDŽIĆ B., ROMIĆ Ž. Quality of groundwater in eastern Croatia. The problem of arsenic pollution. Desalination. 210, 157, 2006.

39. EU's drinking water standards, Council Directive 98/83/ $\mathrm{EC}$ on the quality of water intented for human consumption, Adopted by the Council, on 3 November 1998, accessed 07.10.2012. Available from: http://www.lenntech.com/ applications/drinking/standards/eu-s-drinking-waterstandards.htm.

40. WORLD HEALTH ORGANIZATION, Guidelines for Drinking-water Quality, fourth edition, accessed 07.10.2012. Available from: http://whqlibdoc.who.int/ publications/2011/9789241548151_eng.pdf.

41. MINISTRY OF HEALTH AND WELFARE, Rules on health suitability of drinking water, Annex I, Microbiological, physico-chemical and radiological indicators of drinking water, Zagreb, Croatia, Official Gazette 47, 2008, accessed 07.10.2012. Available from: http://narodne-novine. nn.hr/default.aspx.

42. CORNELIS R., HEINZOW B., HERBER R.F.M., CHRISTENSEN J.M., POULSEN O.M., SABBIONI E., TEMPLETON D.M., THOMASSEN Y., VAHTER M., VESTERBERG O. Sample collection guideliness for trace elements in blood and urine. Pure \& Appl Chem, 67, 1575, 1995.

43. AGUSA T, KUNITO T., MINH T.B., KIM TRANG P.T., IWATA H., VIET P.H., TANABE S. Relationship of urinary arsenic metabolites to intake estimates in residents of the Red River Delta, Vietnam. Environ Pollut, 157, 396, 2009.

44. KAZI T.G., ARAIN M.B., BAIG J.A., JAMALI M.K., AFRIDI H.I., JALBANI N., SARFRAZ R.A., SHAH AQ., 
NIAZ A. The correlation of arsenic levels in drinking water with the biological samples of skin disorders. Sci Total Environ, 407, 1019, 2009.

45. GAULT A.G., ROWLAND H.A., CHARNOCK J.M., WOGELIUS R.A., GOMEZ-MORILLA I., VONG S, LENG M., SAMRETH S., SAMPSON M.L., POLYA D.A. Arsenic in hair and nails of individuals exposed to arsenicrich groundwaters in Kandal province, Cambodia. Sci Total Environ, 393,168, 2008.

46. MANDAL B.K., OGRA Y., ANZAI K., SUZUKI K.T. Speciation of arsenic in biological samples. Toxicol Appl Pharmacol. 198, 307, 2004.

47. SAMANTA G., SHARMA R., ROYCHOWDHURY T., CHAKRABORTI D. Arsenic and other elements in hair, nails, and skin-scales of arsenic victims in West Bengal, India. Sci Total Environ, 326, 33, 2004.

48. IYENGAR V., WOITTIEZ J. Trace elements in human clinical specimens: evaluation of literature data to identify reference values.Clin Chem. 34, 474, 1988.

49. MINOIA C., SABBIONI E., APOSTOLI P, PIETRA R., POZZOLI L., GALLORINI M., NICOLAOU G., ALESSIO L., CAPODAGLIO E. Trace element reference values in tissues from inhabitants of the European community. I. A study of 46 elements in urine, blood and serum of Italian subjects. Sci Total Environ. 95, 89, 1990.

50. OLSON K.R. Poisoning and drug overdose, $4^{\text {th }}$ ed.; McGrawHill Companies: Singapore, pp 118, 2004.

51. OMUR-OZBEK P., DIETRICH A.M. Retronasal perception and flavour thresholds of iron and copper in drinking water. J Water Health, 9, 1, 2011.

52. LONNERDAL B. Bioavailability of copper. Am J Clin Nutr, 63, 821, 1996.

53. GIRI S., MAHATO M.K., SINGH G., JHA V.N. Risk assessment due to intake of heavy metals through the ingestion of groundwater around two proposed uranium mining areas in Jharkhand, India. Environ Monit Assess, 184,1351, 2012.

54. BARTON H. Predicted intake of trace elements and minerals via household drinking water by 6-year-old children from Krakow (Poland). Part 4: Copper. Food Addit Contam Part A Chem Anal Control Expo Risk Assess. 26, 988, 2009.

55. SPITALNY K.C., BRONDUM J., VOGT R.L., SARGENT H.E., KAPPEL S. Drinking-water-induced copper intoxication in a Vermont family. Pediatrics. 74, 1103, 1984.

56. ARAYA M., OLIVARES M., PIZARRO F., GONZALEZ M., SPEISKY H., UAUY R. Gastrointestinal symptoms and blood indicators of copper load in apparently healthy adults undergoing controlled copper exposure. Am J Clin Nutr. 77, 646, 2003.

57. BREWER G.J. Risks of copper and iron toxicity during aging in humans. Chem Res Toxicol. 23, 319, 2010.

58. BREWER G.J. The risks of copper toxicity contributing to cognitive decline in the aging population and to Alzheimer's disease. J Am Coll Nutr, 28, 238, 2009.
59. USEPA, Drinking Water Contaminants, National Primary Drinking Water Regulations, List of Contaminants \& their MCLs, accessed 07.10.2012. Available from: http://water. epa.gov/drink/contaminants/index.cfm.

60. de ROMANA D.L., OLIVARES M., UAUY R., ARAYA M.J. Risks and benefits of copper in light of new insights of copper homeostasis. J. Trace Elem Med Biol. 25, 3, 2011.

61. HARVEY L.J., ASHTON K., HOOPER L., CASGRAIN A., FAIRWEATHER-TAIT SJ. Methods of assessment of copper status in humans: a systematic review. Am J Clin Nutr. 89, 2009, 2009.

62. BRITISH GEOLOGICAL SURVEY. Molybdenum in British drinking water: a review of sources and occurrence and a reconnaissance survey of concentrations, Groundwater Resources Programme, Open Report OR/08/051, accessed 15.03.2013. Available from: http://nora.nerc.ac.uk/3732/1/ OR08051.pdf.

63. TURNLUND J.R., KEYES W.R. Plasma molybdenum reflects dietary molybdenum intake.J Nutr Biochem, 15, 90, 2004.

64. TURNLUND J.R., KEYES W.R., PEIFFER G.L. Molybdenum absorption, excretion, and retention studied with stable isotopes in young men at five intakes of dietary molybdenum. Am J Clin Nutr, 62, 790, 1995.

65. VYSKOCIL A., VIAU C. Assessment of molybdenum toxicity in humans. J Appl Toxicol, 19, 185, 1999.

66. TURNLUND J.R., KEYES W.R., PEIFFER G.L., CHIANG G. Molybdenum absorption, excretion, and retention studied with stable isotopes in young men during depletion and repletion. Am J Clin Nutr, 61, 1102, 1995.

67. WORLD HEALTH ORGANIZATION. Molybdenum in Drinking-water, Background document for development of WHO Guidelines for Drinking-water Quality, accessed 07.10.2012. Available from: http://www.who.int/water sanitation_health/dwq/chemicals/molybdenum.pdf.

68. HUDAK P.F. Elevated fluoride and selenium in west Texas groundwater. Bull Environ Contam Toxicol. 82, 39, 2009.

69. VALENTINE J.L. Environmental occurrence of selenium in waters and related health significance. Biomed Environ Sci, 10, 292, 1997.

70. NRIAGU J., NAM D.H., AYANWOLA T.A., DINH H., ERDENECHIMEG E., OCHIR C., BOLORMAA T.A. High levels of uranium in groundwater of Ulaanbaatar, Mongolia. Sci Total Environ, 414, 722, 2012.

71. BAJAJ M., EICHE E., NEUMANN T., WINTER J., GALLERT C. Hazardous concentrations of selenium in soil and groundwater in North-West India. J Hazard Mater. 189, 640, 2011

72. GUDMUNDSDOTTIR E.Y., GUNNARSDOTTIR I., THORLACIUS A., REYKDAL O., GUNNLAUGSDOTTIR H., THORSDOTTIR I., STEINGRIMSDOTTIR L. Blood selenium levels and contribution of food groups to selenium intake in adolescent girls in Iceland. Food Nutr Res. 56, 18476, 2012. 